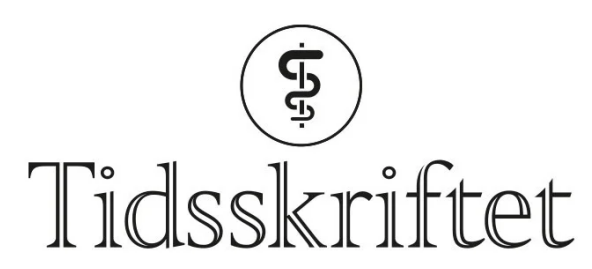

DEN NORSKE LEGEFORENING

\title{
Koronavaksinering av kreftpasienter
}

DEBATT

\section{ODD TERJE BRUSTUGUN}

otr@vestreviken.no

Odd Terje Brustugun er dr.med, spesialist i onkologi og overlege ved Onkologisk seksjon, Drammen sykehus, Vestre Viken.

Forfatteren har fylt ut ICMJE-skjemaet og oppgir ingen interessekonflikter.

\section{LARS HEGGELUND}

Lars Heggelund er dr.med og spesialist i indremedisin og infeksjonssykdommer. Han er overlege ved Medisinsk avdeling og forskningssjef ved Drammen sykehus, Vestre Viken, og førsteamanuensis ved Klinisk institutt 2, Universitetet i Bergen.

Forfatteren har fylt ut ICMJE-skjemaet og oppgir ingen interessekonflikter.

\section{Kreftpasienter ble ekskludert fra de første studiene av vaksiner mot covid-19, men likevel blir disse pasientene anbefalt prioritert for vaksinering. Vi mener kreftpasienter trygt kan vaksineres, men vaksinen bør settes mellom cellegiftkurer.}

Kreftpasienter i aktiv behandling og med metastatisk sykdom er blant de med høyest risiko for alvorlig forløp av covid-19 (1-3). Pasienter med hematologiske kreftformer og lungekreft er særlig utsatt (3). Folkehelseinstituttet definerer pasienter med hematologisk kreftsykdom siste fem år eller annen aktiv kreftsykdom som medisinsk risikogruppe som bør prioriteres for vaksinering (4).

\section{Er effekten av vaksinen like god som hos normalbefolkningen?}

Kreft i seg selv synes ikke å innvirke på immunresponsen etter SARS-CoV-2-infeksjon, med unntak av hematologisk kreft (5), og immunresponsen etter vaksinering hos pasienter med solide kreftformer kan forventes å være like god som i normalbefolkningen. Basert på data fra influensavaksinering kan kanskje pasienter som vaksineres under pågående cellegiftbehandling, få en svakere immunrespons, og noen anbefaler at slike pasienter gis en ekstra dose influensavaksine (므). Om det samme gjelder vaksinene mot SARS-CoV-2viruset, er ikke kjent, men pågående studier undersøker dette (7.). Uansett vil en viss beskyttende immunrespons være bedre enn å gå uvaksinert.

\section{Er det økt risiko for bivirkninger hos kreftpasienter?}


Pasienter i aktiv kreftbehandling ble ekskludert fra de første vaksinestudiene $(\underline{8-10})$. Basert på data fra andre vaksinetyper er kreftpasienter neppe mer utsatt for bivirkninger enn andre. De tilgjengelige mRNA-baserte covid-19-vaksinene utgjør ikke noen risiko for pasienter med nedsatt immunforsvar. Dette er ikke levende vaksiner, og samme vaksineteknologi utprøves også som terapeutiske kreftvaksiner (11). Den såkalte AstraZeneca/Oxford-vaksinen er basert på en adenovirus-vektor som ikke er i stand til å replikere i humane celler, og utgjør heller ingen risiko for pasienter med svekket immunforsvar (므).

\section{«De tilgjengelige mRNA-baserte covid-19-vaksinene utgjør ikke noen risiko for pasienter med nedsatt immunforsvar»}

Så langt er det ikke kommet rapporter som indikerer økt bivirkningsforekomst blant covid-19-vaksinerte kreftpasienter.

\section{Når bør vaksinen settes?}

Cellegiftbehandling virker immunsuppressivt og kan redusere immunresponsen etter vaksine. Også spesifikk B-cellehemmende behandling, som med rituksimab, vil kunne ha slik effekt. Imidlertid induserer covid-19-vaksinene også en potent og gunstig T-

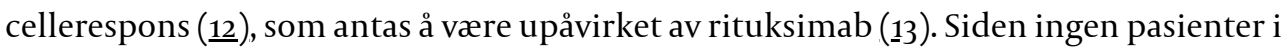
aktiv kreftbehandling ble inkludert i vaksinestudiene, vet vi lite om hva som er det beste tidspunktet for vaksinering for disse pasientene. Basert på relativt små studier av influensavaksinering av kreftpasienter er det trolig mest gunstig å sette vaksinen mellom cellegiftkurer, og ikke samme dag som cellegiftinfusjonen $(\underline{6}, \underline{14})$.

Pasienter som behandles med immunsjekkpunkthemmere (anti-PD-1/-PD-L1/-CTLA-4) eller proteinkinasehemmere, synes ikke å ha påvirket antistoffrespons eller økte bivirkninger av influensavaksinasjon, og koronavaksinering kan trolig gjennomføres uten å ta hensyn til tidspunkt for immunterapiinfusjon eller pågående målrettet behandling(15).

\section{LITTERATUR}

1. Nystad W, Hjellvik V, Larsen IK et al. Underliggende tilstander hos voksne med covid-19. Tidsskr Nor Legeforen 2020; 140. doi: 10.4045/tidsskr.20.0512. [PubMed][CrossRef]

2. Kvåle R, Bønaa KH, Forster R et al. Hva betyr tidligere hjerte- og karsykdom eller kreft for risiko for død etter påvist sars-CoV-2? Tidsskr Nor Legeforen 2021; 141. doi: 10.4045/tidsskr.20.0956. [CrossRef]

3. Wang Q, Berger NA, Xu R. Analyses of Risk, Racial Disparity, and Outcomes Among US Patients With Cancer and COVID-19 Infection. JAMA Oncol 2020 doi: 10.1001/jamaoncol.2020.6178. [PubMed] [CrossRef]

4. Hvem kan få koronavaksine? Oslo: Folkehelseinstituttet, 2021.

<https://www.fhi.no/sv/vaksine/koronavaksinasjonsprogrammet/hvem-kan-fa-koronavaksine/>. Lest 11.1.2O21.

5. Abdul-Jawad S, Baù L, Alaguthurai T et al. Acute immune signatures and their legacies in severe acute respiratory syndrome coronavirus-2 infected cancer patients. Cancer Cell 2021 doi: 10.1016/j.ccell.2021.01.001. [CrossRef]

6. Rousseau B, Loulergue P, Mir O et al. Immunogenicity and safety of the influenza A H1N1v 2009 vaccine in cancer patients treated with cytotoxic chemotherapy and/or targeted therapy: the VACANCE study. Ann Oncol 2012; 23: 450-7. [PubMed][CrossRef]

7. Au L, Boos LA, Swerdlow A et al. Cancer, COVID-19, and Antiviral Immunity: The CAPTURE Study. Cell 2020; 183: 4-10. [PubMed][CrossRef]

8. Polack FP, Thomas SJ, Kitchin N et al. Safety and Efficacy of the BNT162b2 mRNA Covid-19 Vaccine. N Engl J Med 2020;383: 2603-15. [PubMed][CrossRef] 
9. Baden LR, El Sahly HM, Essink B et al. Efficacy and Safety of the mRNA-1273 SARS-CoV-2 Vaccine. N Engl J Med 2020; NEJMoa2035389. [PubMed][CrossRef]

10. Voysey M, Clemens SAC, Madhi SA et al. Safety and efficacy of the ChAdOx1 nCoV-19 vaccine (AZD1222) against SARS-CoV-2: an interim analysis of four randomised controlled trials in Brazil, South Africa, and the UK. Lancet 2020 doi:10.1016/So140-6736(20)32661-1. [PubMed][CrossRef]

11. Esprit A, de Mey W, Bahadur Shahi R et al. Neo-Antigen mRNA Vaccines. Vaccines (Basel) 2020; 8: E776. [PubMed][CrossRef]

12. Sahin U, Muik A, Derhovanessian E et al. COVID-19 vaccine BNT162b1 elicits human antibody and TH1 T cell responses. Nature 2020; 586: 594-9. [PubMed][CrossRef]

13. Baker D, Roberts CAK, Pryce G et al. COVID-19 vaccine-readiness for anti-CD2o-depleting therapy in autoimmune diseases. Clin Exp Immunol 2020; 202:149-61. [PubMed][CrossRef]

14. Loulergue P, Alexandre J, Iurisci I et al. Low immunogenicity of seasonal trivalent influenza vaccine among patients receiving docetaxel for a solid tumour: results of a prospective pilot study. $\mathrm{Br}$ J Cancer 2011; 104: 1670-4. [PubMed][CrossRef]

15. Bayle A, Khettab M, Lucibello F et al. Immunogenicity and safety of influenza vaccination in cancer patients receiving checkpoint inhibitors targeting PD-1 or PD-L1. Ann Oncol 2020;31: 959-61. [PubMed][CrossRef]

Publisert: 15. januar 2021. Tidsskr Nor Legeforen. DOI: 10.4045/tidsskr.21.0026 Mottatt 10.1.2021, godkjent 12.1.2021.

(C) Tidsskrift for Den norske legeforening 2023. Lastet ned fra tidsskriftet.no 26. april 2023. 